\title{
Strategic analysis as a tool for development of a transport company (on the example of the company from the Tyumen city)
}

\author{
E.G. Makovetskaya ${ }^{1}$, and E. G. Yuzikhanova ${ }^{2 *}$ \\ ${ }^{1}$ Tyumen Industrial University, Volodarskogo str., 38, Tyumen, 625000, Russia \\ ${ }^{2}$ Tyumen Advanced Training Institute of the MIA of Russia, Amur str., 75, Tyumen, 625049, Russia
}

\begin{abstract}
The article presents an assessment of the activities of the construction company from the Tyumen city. An important stage in developing an effective strategy of the company is strategic analysis, which should give a real assessment of own resources and capabilities in relation to the state (and needs) of the external environment in which the firm operates. On the basis of this analysis, rational choice of strategies from a possible set of options should occur. The conducted SWOTanalysis has allowed to formulate the potential directions, capable to make financial indicators of the construction company much better.
\end{abstract}

\section{Introduction}

The most important stage in the development of an effective strategy of the company is strategic analysis, which should give a real assessment of own resources and capabilities in relation to the state (and needs) of the external environment in which the firm operates. Rational choice of strategies from a possible set of options should be based on this analysis.

The most common and attractive methods are SWOT-analysis and PEST-analysis. SWOT-analysis allows you to assess the external and internal environment of the organization. PEST-analysis is aimed at assessing the political, economic, social and technological aspects of the market environment.

The article presents a SWOT analysis conducted for ALEX-Group LLC. The company "ALEX-Group", the company for the production of complex works in the field of industrial and civil construction.

The company renders services in the field of new design, inspection of industrial and civil buildings and structures, technical testing of building structures, develops projects for reconstruction, repair of buildings and structures, develops technical solutions for strengthening structures and foundations. Also the main direction of the company is the development of solutions for waterproofing, dewatering and drainage systems.

The geography of the works of LLC "ALEX-Group" stretches from the peninsula Crimea to the Kuril Islands. ALEX-Group conducts scientific research in the field of

${ }^{*}$ Corresponding author: Yuzikhanova@mail.ru 
foundations. At the present time, the main direction of scientific research of the company is the strengthening of weak bases by geosynthetic materials and injection methods.

The main activities of "ALEX-Group" LLC are presented in Table 1.

Table 1. Areas of work of "ALEX-Group" LLC

\begin{tabular}{|c|l|}
\hline No & \multicolumn{1}{|c|}{ Name of areas of work } \\
\hline 1 & Design of buildings and structures (including using BIM-modeling) \\
\hline 2 & $\begin{array}{l}\text { Inspection of buildings and structures, technical tests, examination, laboratory tests, } \\
\text { scientific and technical support }\end{array}$ \\
\hline 3 & $\begin{array}{l}\text { Development of projects for strengthening, reconstruction and repair of buildings, } \\
\text { structures and foundations }\end{array}$ \\
\hline 4 & $\begin{array}{l}\text { Development of projects for geotechnical and underground works (including engineering- } \\
\text { geological, geotechnical and geophysical prospecting, field testing) }\end{array}$ \\
\hline 5 & $\begin{array}{l}\text { Development of waterproofing projects for buildings and structures, dewatering, drainage } \\
\text { systems }\end{array}$ \\
\hline 6 & $\begin{array}{l}\text { Works on the repair and strengthening of buildings and structures and their individual } \\
\text { structures (including the use of modern injection methods and carbon plastics) }\end{array}$ \\
\hline 7 & $\begin{array}{l}\text { Special works with the use of modern building chemistry, technologies and materials } \\
\text { (injection, protection, repair, anchor, geosynthetics and membranes) }\end{array}$ \\
\hline 8 & $\begin{array}{l}\text { Works on the arrangement and strengthening of foundations, excavations, slopes and } \\
\text { embankments, monitoring of buildings and structures }\end{array}$ \\
\hline
\end{tabular}

\section{Methods}

SWOT is an acronym for the initial letters of English words: Strengths, Weaknesses, Opportunities, Threats.

Thus, SWOT-analysis is a definition of strengths and weaknesses of an enterprise, as well as opportunities and threats emanating from its immediate environment (external environment). The attractiveness and popularity of this method is connected, on the one hand, with its simplicity, universality and accessibility, on the other hand, with the possibility of an integrated view of the company and its business environment.

Strength is an internal characteristic of the company, which distinguishes this enterprise from competitors.

Weakness is the internal characteristic of the company, which in relation to the competitor looks weak (undeveloped), and which the company is able to improve.

Opportunity is a characteristic of the external environment of the company (i.e. the market), which gives all participants of this market an opportunity to expand their business.

Threat is a characteristic of the external environment of the company (i.e. the market), which reduces the attractiveness of the market for all participants.

The purpose of the SWOT analysis is to formulate the main directions of the enterprise development through the systematization of available information about the strengths and weaknesses of the firm, as well as potential opportunities and threats.

\section{Results}

SWOT-analysis of the company "ALEX-Group" LLC is presented in Table 2. 
Table 2. SWOT-analysis of "ALEX-Group" LLC

\begin{tabular}{|c|c|}
\hline $\begin{array}{l}\text { STRENGTHS } \\
\text { Established relationships with suppliers } \\
\text { The financial position of the organization } \\
\text { is stable } \\
\text { Relatively stable staff } \\
\text { Competitive quality of services } \\
\text { Respectful attitude of clients (customer } \\
\text { loyalty, availability of permanent clients) } \\
\text { Organization Flexibility } \\
\text { Modern software }\end{array}$ & $\begin{array}{l}\text { WEAKNESSES } \\
\text { Low level of the general condition of marketing } \\
\text { (small popularity of the company) } \\
\text { Lack of customer base management system } \\
\text { Most of the employees work under fixed-term } \\
\text { contracts } \\
\text { Formal level of regulatory documentation } \\
\text { Small scale of activity } \\
\text { The price policy is based on market prices (targeting } \\
\text { competitors) }\end{array}$ \\
\hline $\begin{array}{l}\text { OPPORTUNITIES } \\
\text { Required direction of special works } \\
\text { Receiving larger orders } \\
\text { The emergence of new technologies that } \\
\text { reduce the cost of production }\end{array}$ & $\begin{array}{l}\text { THREATS } \\
\text { Objects in the Crimea and the Kuril Islands are } \\
\text { geographically not mobile. The change in legislation } \\
\text { Rise in rent } \\
\text { Material supply failure } \\
\text { The emergence of strong competitors in the market }\end{array}$ \\
\hline
\end{tabular}

Table 3 shows the interpretation of the raw data for SWOT analysis.

Table 3. Interpretation of SWOT analysis

\begin{tabular}{|c|c|c|}
\hline & STRENGTHS & WEAKNESSES \\
\hline 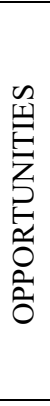 & $\begin{array}{l}\text { SECTOR "DEVELOPMENT" } \\
\text { Maintaining relationships with } \\
\text { suppliers, expanding their list } \\
\text { Study of current technologies that } \\
\text { reduce the cost of production }\end{array}$ & $\begin{array}{l}\text { SECTOR "WHAT TO CHANGE" } \\
\text { Revision of the attitude to various marketing } \\
\text { channels, the introduction of various advertising } \\
\text { tools } \\
\text { Formation of the customer base management system } \\
\text { Working out the issue of social protection of } \\
\text { workers } \\
\text { Audit of existing regulatory documentation, transfer } \\
\text { from a formal approach to working tools } \\
\text { Development of special work direction } \\
\text { Participation in tender auctions }\end{array}$ \\
\hline 次 & $\begin{array}{l}\text { SECTOR "COMPENSATION OF } \\
\text { THREATS" } \\
\text { For stable development of the } \\
\text { enterprise, a stable staff } \\
\text { composition is required } \\
\text { Constant monitoring of legislative } \\
\text { changes }\end{array}$ & $\begin{array}{l}\text { Development of measures to improve the quality of } \\
\text { services } \\
\text { Study of factors of competitiveness of other firms } \\
\text { providing similar services }\end{array}$ \\
\hline
\end{tabular}

SWOT-analysis made it possible to identify the following areas of development of the activities of "ALEX-Group" LLC:

1. Working out the issue of social protection of workers;

2. Audit of existing regulatory documentation, transition from a formal approach to working tools;

3. Expanding the list of suppliers;

4. Tracking of current technologies, with the purpose of revealing the cost-cutting products;

5. Creating conditions for the formation of a sustainable staffing;

6. Continuous monitoring of legislative changes;

7. Revising the attitude to various marketing channels, the introduction of various advertising tools; 
8. Formation of the customer base management system;

9. Development of special work direction;

10. Participation in tender auctions;

11. Development of measures to improve the quality of services;

12. Analysis of factors of competitiveness of other firms providing similar services.

\section{Conclusions}

SWOT-analysis has made it possible to identify the directions for the development of the designated company. But it is important to understand that each of the formulated directions requires separate decisions and close monitoring.

Work on the issue of social protection of workers is possible after studying the needs of staff. Many employees work in this construction company on fixed-term contracts from year to year. This is due to certain values of people and the seasonal factor. Many employees see the advantage in the fact that the key orders of "ALEX-Group" LLC is realized from April to November. Workers spend the winter period not in Russia, but in milder (climatically) countries. Social security (official stable employment) can complicate the realization of the indicated life model.

Audit of existing regulatory documentation and transfer from a formal approach to working tools is an important area. First of all, this is due to the fact that the company is developing (the number of employees, serviced facilities, expansion of geography, etc.) and for the management of the enterprise it is important to work out a methodical part of implementing management decisions. The introduction of regulations is inevitable, as is the control over their implementation. This is also important for creating the conditions for the formation of a sustainable staffing.

Expanding the list of suppliers will allow the company to achieve a more sustainable position: prompt replacement in case of a breach of the delivery or assortment.

Tracking of actual technologies, with the purpose of revealing the cost-cutting products, is possible by participation in the exhibition activity.

Constant monitoring of legislative changes is inevitable. This risk affects all the organizations operating in the market.

Revising the attitude to different marketing channels, the introduction of various advertising tools can be a field of opportunity. "ALEX-Group" LLC is not widely known, therefore certain orders may be missed.

Formation of the customer base management system will allow the organization to build long-term relationships and manage staff loyalty.

Thus, the SWOT-analysis presented in the article made it possible to identify the problems that currently exist for "ALEX-Group" LLC. The company is developing and the strategic vision of the development of the situation and the withdrawal of managerial processes to a new level becomes especially topical for management. Important blocks are the timely establishment of all processes, which is impossible without identifying competitive advantages and "narrow" places of the company. In addition to comparing with competitors, it is important to take into account general market trends.

\section{References}

1. V. Lezier, M. Gusarova, A. Kopytova, IOP Conference Series: Earth and Environmental Science, 90 (1), 012034 (2017) DOI: 10.1088/1755-1315/90/1/012034

2. N. Zotkina, A. Kopytova, M. Zenkina, O. Zhigunova, MATEC Web of Conferences, 106, 08058 (2017) DOI: 10.1051/matecconf/201710608058 
3. A. Minnullina, R. Abdrazakov, Advances in Intelligent Systems and Computing 692, 1224-1233 (2018) DOI: 10.1007/978-3-319-70987-1_131

4. A.V. Kopytova, Exchange of intellectual property 3 (XIV), 31-37 (2015)

5. V. Lezier, M. Gusarova, A. Kopytova, IOP Conference Series: Earth and Environmental Science, 90 (1), 012069 (2017) DOI: 10.1088/1755-1315/90/1/012069

6. A. Mottaeva, A. Minnullina, IOP Conference Series: Earth and Environmental Science, 90 (1), 012123 (2017) DOI: 10.1088/1755-1315/90/1/012123

7. N. Zotkina, M. Gusarova, A. Kopytova, Advances in Intelligent Systems and Computing 692, 1204-1213 (2018) DOI: 10.1007/978-3-319-70987-1_129

8. A. Kopytova, Procedia Engineering 165, 1132 (2016) DOI: 10.1016/j.proeng.2016.11.830

9. K. Pykhtin, T. Simankina, V. Sharmanov, A. Kopytova, IOP Conference Series: Earth and Environmental Science, 90 (1), 012065 (2017) DOI: 10.1088/1755$1315 / 90 / 1 / 012065$

10. M. Gravit, O. Zybina, A. Vaititckii, A. Kopytova, IOP Conference Series: Earth and Environmental Science, 90 (1), 012103 (2017) DOI: 10.1088/1755-1315/90/1/012103

11. A. Kopytova, MATEC Web of Conferences, 106, 08056 (2017) DOI: $10.1051 /$ matecconf $/ 201710608056$

12. N. Zotkina, S. Bardasov, M. Gusarova, A. Kopytova, MATEC Web of Conferences, 106, 08050 (2017) DOI: 10.1051/matecconf/201710608050

13. Fedorov, M., Matys, E., Kopytova, A. E3S Web of Conferences, 33, 03054 (2018) DOI: $10.1051 / \mathrm{e} 3$ sconf/20183303054 